\author{
목초액 함유 활성탄의 급여가 산란계에서 계란의 품질과 \\ 화학적 조성에 미치는 영향 \\ 김관응* . 유선종* . 안병기* . 조태수** . 안병준** . 최돈하** . 강창원* \\ 건국대학교 축산대학 동물자원연구센터*, 국립산림과학원 화학미생물과**
}

\title{
Effects of Dietary Activated Charcoal Mixed with Wood Vinegar on Quality and Chemical Composition of Egg in Laying Hens
}

\author{
K. E. Kim*, S. J. You*, B. K. Ahn*, T. S. Jo**, B. J. Ahn**, D. H. Choi** and C. W. Kang*
}

Animal Resources Research Center, College of Animal Husbandry, Konkuk University* and Div. Wood Chemistry \& Microbiology, Korea Forest Research Institute**

\begin{abstract}
This experiment was conducted to investigate the effects of dietary supplementation of activated charcoal (AC) mixed with wood vinegar on performance and egg quality in laying hens. A total of one hundred ninety two, 56-wk-old Lohmann brown laying hens were divided into four groups, consisting four replicates of 12 birds each and fed one of the four experimental diets containing AC $0 \%$, AC $0.5 \%$, AC $1 \%$, AC $2 \%$ for 5 wks. The blood profiles and contents of total lipid and cholesterol, fatty acid profiles in egg yolk were determined. There were no significant differences in laying performance, feed intake and vitelline membrane strength among the treatments. The eggshell breaking strength and Haugh unit were significantly increased in $2 \%$ AC group compared to the other groups $(\mathrm{P}<0.05)$. Egg yolk index in $2 \%$ AC group was significantly higher $(\mathrm{P}<0.05)$ than those of the control and $0.5 \%$ AC group and yolk color was significantly improved by the dietary AC $(\mathrm{P}<0.05)$. The levels of serum total cholesterol, HDL-cholesterol and enzyme activities were not influenced by feeding AC. Total lipid of egg yolk in $1 \%$ and $2 \%$ AC groups was significantly decreased $(\mathrm{P}<0.05)$ compared to that of the control, although there was no significant difference in yolk cholesterol. In conclusion, the addition of activated charcoal with wood vinegar in layer diet resulted in improving egg quality by means of enhancing eggshell breaking strength, Haugh unit, yolk index and yolk color.
\end{abstract}

(Key words : Activated charcoal, Wood vinegar, Performance, Eggshell breaking strength, Haugh unit, Laying hens)

\section{I. 서 론}

목탄과 목초액은 동물산업 분야에서 생산성 향상과 생리활성의 부여를 목적으로 이미 오래 전부터 다양하게 연구되었던 물질이다. 활성탄 은 토양개량제로서 사용되며(Kishimoto와 Sugiura,
1985), 방부 및 방충효과(Buck와 Bratich, 1985), 식물의 발육촉진(Bamberg 등, 1986), 탈취 효과 (Bradley 등, 1987), 환경 정화 효과(Guo 등, 1991) 그리고 가축의 질병 치료 및 예방 효과 (Dalvi와 Ademoyer, 1984)를 발휘하며, 발육 촉 진 및 호르몬 분비에 영향을 미치는 것으로 알

Corresponding author : Dr. C. W. Kang, Animal Resources Research Center, College of Animal Husbandry, Konkuk University, 1 Hwayang-dong, Gwangjin-gu, Seoul 143-701, Korea TEL : 82-2-450-3669, FAX : 82-2-452-9946 E-mail : kkucwkang@empal.com 
려져 왔다(Hinshelwood 등, 1991). 특히 활성탄 은 미세한 공극이 많아 불순물과 특정 물질을 흡착 및 탈취시키는 기능이 있고, 흡착 능력이 우수한 저회분의 특징이 있으며, 가축에서 사 료첨가제로서 공급하여도 큰 부작용은 없는 것 으로 알려져 있으며(성기승 등, 1997), 활성탄을 이용한 고부가가치 축산물의 생산 가능성도 시 사되었다(황미자, 1995).

활성탄 제조 시 생산되는 목초액은 약 200여 종의 다양한 성분이 함유되어 그 중에서 약 50 여 종이 생리 활성을 발휘하는 등 체내 대사를 원활히 유지하는데 관여한다고 보고되었다(김 광은 등, 2000). 목초액은 80-90\%의 수분과 10 - 20\%의 유기물이 존재하여 악취 제거에 효과 적이며(허광선 등, 1998), 인체의 건강과 질병의 치료에도 활용 가능성이 있는 것으로 그 유익 한 효과가 시사되었다(김성훈과 김한성, 1998). 최근에는 목초액을 정제한 건강보조식품과 목 초액이 첨가된 사료를 급여하여 생산된 계란이 시중에 판매되고 있으며, 목초액을 활성탄에 흡착시킨 것을 가축에 사용하기도 한다. 활성 탄을 이용한 가축의 사료 내 첨가로 인한 효과 는 육계의 경우 oleic acid 및 arachidonic acid의 함량과 $\mathrm{Ca}, \mathrm{Mg}$ 및 $\mathrm{P}$ 함량이 유의하게 증가하 며, 지방 함량이 감소된다는 결과가 관찰되었 고(김영직과 박창일, 2001), 돼지에서의 활성탄 급여는 돈육의 기호성과 조직적 특성에 영향을 미치는 것으로 보고하였다(문성실, 2002).

본 실험에서는 산란후기의 공시계를 이용하 여 시중에서 유통되고 있는 목초액이 첨가된 활성탄(activated charcoal, AC)의 수준별 첨가 급여가 난 생산성 및 생리적 반응에 미치는 영 향을 조사하였고, 생산된 계란의 품질에 미치 는 영향을 알아보고자 실시하였다.

\section{ㅍ. 재료 및 방법}

\section{1. 실험 시료}

본 실험에 사용된 활성탄 시료는 목탄분에 정제한 목초액을 첨가하여 $(v / v \quad 7: 3)$ 사료첨가제 용으로 제조하여 판매하는 제품을 이용하였다.

\section{2. 실험사료 및 실험동물}

실험에 사용된 사료는 옥수수-대두박을 기초 로 하여 대사에너지 $2,750 \mathrm{kcal} / \mathrm{kg}$ 와 $16 \%$ 의 조 단백질 그리고 기타 영양소의 수준은 NRC 요 구량(1994)을 다소 상회하도록 하였으며, 가루 형태로 제조하여 대조구 사료로 사용하였다. 대조구 사료에 중량 대비 $0.5 \%, 1.0 \%$ 및 $2.0 \%$ 수준으로 활성탄을 첨가하여 급여 실험을 실시 하였다(Table 1).

56주령의 Lohmann Brown 산란 실용계 192수 를 공시하였다. 2주간 전용 산란계 케이지(너비 $42 \mathrm{~cm}$, 깊이 $34 \mathrm{~cm}$; 수당 약 $480 \mathrm{~cm}^{2}$ )에서 3 수씩 사육하였고 처리당 4 반복, 반복당 12 수씩 완전 임의 배치하였다. 2주간의 예비실험을 통해 사 료섭취량, 산란율 및 난중이 처리구별로 유사 하도록 조정한 후 5 주간의 본 실험을 실시하였 다.

\section{3. 사양 관리}

본 실험은 외부 환경에 의한 영향을 최소로 줄일 수 있도록 온도와 점등을 조절할 수 있는 산란계 시험용 무창 계사에서 실시하였으며, 물과 사료는 자유 음수 및 자유 채식시켰다. 전 실험기간 중 사육실 온도는 $25 \pm 3^{\circ} \mathrm{C}$ 로 하였 으며, 기타 일반적인 사양관리는 관행적인 방 법에 준하여 실시하였다. 수당 급이 면적과 반 복당 급수기 숫자는 동일하도록 하였고, 시험 전 기간 동안 점등은 $15 \mathrm{~L}: 9 \mathrm{D}$ 로 일정하게 유지 하였다.

\section{4. 조사 항목}

\section{1) 사료섭취량과 난 생산성}

사료섭취량은 매주 총 급여량에서 잔량을 제외하여 측정하였고, 실험 기간 동안 매일 오후 4시에 수집한 산란 개수와 연란, 파란 등을 합한 총 산란 개수를 사육수수로 나누어 산란율을 구하였으며, 수집된 전부를 칭량하 여 계란 수로 나누어 평균 난중을 산출하였 다. 
Table 1. Composition of the experimental diets ${ }^{1)}$

\begin{tabular}{|c|c|c|c|c|}
\hline Items & AC $0 \%$ & AC $0.5 \%$ & AC $1 \%$ & AC $2 \%$ \\
\hline Yellow corn & 58.26 & 58.16 & 57.76 & 57.40 \\
\hline Soybean meal & 16.18 & 15.98 & 15.88 & 15.24 \\
\hline Hulled lupin & 3.00 & 3.00 & 3.00 & 3.00 \\
\hline Wheat meal & 2.00 & 2.00 & 2.00 & 2.00 \\
\hline Corn gluten meal & 2.00 & 2.00 & 2.00 & 2.00 \\
\hline Wheat bran & 2.50 & 2.50 & 2.50 & 2.50 \\
\hline Canola meal & 3.20 & 3.00 & 3.00 & 3.00 \\
\hline Tallow & 1.60 & 1.60 & 1.60 & 1.60 \\
\hline Molasses & 0.50 & 0.50 & 0.50 & 0.50 \\
\hline Limestone, coarse & 9.40 & 9.40 & 9.40 & 9.40 \\
\hline Dicalcium phosphate & 0.64 & 0.64 & 0.64 & 0.64 \\
\hline Salt & 0.30 & 0.30 & 0.30 & 0.30 \\
\hline DL-Methionine & 0.03 & 0.03 & 0.03 & 0.03 \\
\hline Choline-chloride (50\%) & 0.05 & 0.05 & 0.05 & 0.05 \\
\hline Mineral $\operatorname{mix}^{2}$ & 0.15 & 0.15 & 0.15 & 0.15 \\
\hline Vitamin $\operatorname{mix}^{3)}$ & 0.13 & 0.13 & 0.13 & 0.13 \\
\hline Mycotoxin binder & 0.03 & 0.03 & 0.03 & 0.03 \\
\hline Natuphos & 0.03 & 0.03 & 0.03 & 0.03 \\
\hline Vital Force Powder ${ }^{(\mathrm{R})}$ & 0 & 0.50 & 1.00 & 2.00 \\
\hline Total & 100.00 & 100.00 & 100.00 & 100.00 \\
\hline \multicolumn{5}{|c|}{ Calculated values of experimental diets } \\
\hline Dry matter, \% & 89.12 & 89.11 & 89.08 & 89.04 \\
\hline Crude protein, \% & 16.00 & 15.97 & 15.94 & 15.91 \\
\hline Ether Extract, \% & 4.45 & 4.43 & 4.41 & 4.39 \\
\hline Crude Fiber, \% & 3.69 & 3.68 & 3.67 & 3.66 \\
\hline Ash, \% & 12.77 & 13.27 & 13.77 & 14.77 \\
\hline Available P, \% & 0.21 & 0.21 & 0.21 & 0.21 \\
\hline Ca, \% & 3.86 & 3.87 & 3.90 & 3.92 \\
\hline TMEn, kcal/kg & 2,750 & 2.740 & 2,725 & 2,700 \\
\hline
\end{tabular}

1) Abbreviation used : AC, activated charcoal.

2) Mineral mixture provided following nutrients per $\mathrm{kg}$ of diet : Fe, $70 \mathrm{mg} ; \mathrm{Zn}, 60 \mathrm{mg} ; \mathrm{Mn}, 8 \mathrm{mg} ; \mathrm{Cu}, 7.5 \mathrm{mg}$; I, $1 \mathrm{mg}$; Se, $0.2 \mathrm{mg}$; Co, $0.13 \mathrm{mg}$

3) Vitamin mixture provided following nutrients per kg of diet : vitamin A, 10,000 IU; vitamin $\mathrm{D}_{3}, 2,300 \mathrm{IU}$; vitamin $\mathrm{E}, 20 \mathrm{IU}$; vitamin $\mathrm{K}_{3}, 2 \mathrm{mg}$; vitamin $\mathrm{B}_{1}, 2 \mathrm{mg}$; vitamin $\mathrm{B}_{2}, 5 \mathrm{mg}$; vitamin $\mathrm{B}_{6}, 3.5 \mathrm{mg}$; vitamin $\mathrm{B}_{12}$, $0.02 \mathrm{mg}$; biotin, $0.12 \mathrm{mg}$; niacin, $30 \mathrm{mg}$; pantothenic acid, $10 \mathrm{mg}$; folic acid, $0.7 \mathrm{mg}$.

\section{2) 혈액 콜레스테롤 농도}

5주간의 실험 종료 후, 처리구 별로 8수씩 선발한 공시계의 익하 정맥에서 1 회용 주사기 로 혈액을 채취한 후 원심분리(1500 rpm $\times$ $15 \mathrm{~min})$ 하여 혈청을 분리하였으며, 진단용 콜레 스테롤 kit (콜레스테롤 E kit, HDL-콜레스테롤 kit, 영동제약)를 사용하여 비색방법으로 총 콜 레스테롤 및 $\mathrm{HDL}$-콜레스테롤 농도를 측정하 였다.

\section{3) 간 기능 관련 효소의 활성}

혈청 내의 glutamic-oxaloacetic transaminase (GOT) 및 glutamic-pyruvic transaminase (GPT) 활성은 GOT-GPT kit (BCS GOT-GPT 측정용 kit, Bio Clinical System Corporation)를 사용하여 비색방법으로 측정하였다.

\section{4) 난질 및 난각질}

실험 사료 급여 후 매주 생산된 계란 중 평 
균치에 해당하는 계란을 수집하여 난각 강도, 난각 두께 및 난황계수, Haugh unit 등 계란의 내부 난질 및 난각질 관련 항목을 측정하였다. 난각 강도는 난각 강도계(FHK 卵殼强度計, 富 土乎工業株式會社)를 이용하여 계란의 둔단부 를 위로 하고 수직으로 고정한 후 압력을 가하 여 파각되는 순간의 압력을 측정하였다. 난각 강도 측정 후 난백의 높이를 조사하여 난중을 대비한 Haugh unit 수치를 구하였다(FHK 畉白 測定台, 富土乎工業株式會社). 난각 두께는 계 란의 중앙부 난각 파편을 채취하여 난각 후도 계(FHK Peacock, 富土平工業株式會社)를 통해 측정한 두께의 평균치로 하였다. 난황계수는 켈리퍼스로 난황의 높이와 직경을 측정하여 Sauter 등(1951)의 방법에 의하여 난황의 높이 를 난황의 직경으로 나누어 계산하였다.

매주 생산된 계란 중 평균치에 해당하는 계 란을 수집하여 실온에서 보존하였다. 실험 3주 와 5주째 1 일 저장한 계란과 7 일 및 14 일 저장 한 계란의 난황막 강도를 측정하였다. 난황막 강도는 Texture Analyzer (TX-XT2i, Stable Micro System, USA)를 이용하였고, 이 때 probe는 직 경 $5 \mathrm{~cm}$ (NHK Corporation)로 Load Cell은 $5 \mathrm{~kg}$ 을 사용하였다.

5) 난황 총지방, 콜레스테롤 함량 및 지방산 조성

실험 종료 5 주째 얻은 계란을 할란하여 난황 만 취한 후 AOAC를 변형시킨 방법(Mark 등, 1996) 및 Folch 법(Folch 등, 1957)에 따라 총지 질을 추출하였다. 검화 및 derivatization 과정을 통해 얻어진 시료는 $30 \mathrm{~m} \times 0.25 \mathrm{~mm}$ id $\times 0.25 \mathrm{um}$ film thickness (SACTM-5, Supelco) fused silica capillary column과 detector FID를 장착한 $\mathrm{GC}$
(Hewlett packard 5890 series $\Pi$; Hewlett packard 6890 series injector)를 이용하여 분석하였다. Carrier로는 helium을 이용하였고, 초기 온도와 최종 온도는 $280^{\circ} \mathrm{C}$, detector 온도는 $300^{\circ} \mathrm{C}$ 로 설 정하였다.

난황에서 추출한 총지질 중 일부를 지방산 조성의 분석을 위한 사료로 사용하였다. Methylation과 중화반응을 통해 최종적으로 얻어진 시료를 GC (Hewlett packard 6890 series)에 injection 하였다. Omegawa 320 capillary column $(30 \times 0.32 \mathrm{~mm}$ ID)을 이용하였고, column 초기 온도는 $180^{\circ} \mathrm{C}$ 로 하였으며, 분당 $2.5^{\circ} \mathrm{C}$ 씩 승온시 켜 최종 온도는 $220^{\circ} \mathrm{C}$ 로 하였다. Detecter와 injection port의 온도는 각각 $250^{\circ} \mathrm{C}$ 로 하였다. Carrier gas로는 helium을 사용하였다.

\section{5. 통계 분석}

모든 얻어진 결과에 대한 통계분석은 SAS (SAS, 2002)의 GLM 프로그램을 이용하여 실시 하였고 분산분석상에 통계적인 유의차가 인정 될 때 Duncan의 다중검정을 이용하여 처리간의 유의성을 검정하였다(Duncan, 1955).

\section{III. 결과 및 고찰}

\section{1. 산란율, 난중 및 사료 섭취량에 미치는 영향}

실험사료 내 활성탄(activated charcoal, AC)을 $0 \%, 0.5 \%, 1.0 \%$ 및 $2.0 \%$ 수준으로 첨가하여 급 여했을 때 전 실험기간 중의 평균 산란율, 난 중 및 일당 사료섭취량에 미치는 영향에 대한 결과를 Table 2에 나타내었다. AC $1 \%$ 및 $2 \%$

Table 2. Effects of dietary activated charcoal on laying performances and feed intake in laying hens ${ }^{1), 2)}$

\begin{tabular}{lrrrr}
\hline & \multicolumn{1}{c}{ AC 0\% } & \multicolumn{1}{c}{ AC 0.5\% } & \multicolumn{1}{c}{ AC 1\% } & \multicolumn{1}{c}{ AC 2\% } \\
\hline \hline Egg production rate, \% & $71.37 \pm 1.75$ & $71.52 \pm 0.86$ & $75.02 \pm 2.55$ & $74.08 \pm 0.91$ \\
Egg weight, g/egg & $64.07 \pm 0.35$ & $62.89 \pm 0.34$ & $63.80 \pm 0.23$ & $64.42 \pm 0.13$ \\
Feed intake, g/hen/day & $118.0 \pm 0.82$ & $118.4 \pm 1.68$ & $121.2 \pm 3.77$ & $123.6 \pm 1.83$ \\
\hline
\end{tabular}

1) Abbreviation used : AC, activated charcoal.

2) Means \pm SE. 
첨가구의 전 실험기간 중의 평균 산란율은 각 각 $75.02 \%$ 및 $74.08 \%$ 로 대조구 $71.37 \%$ 에 비해 다소 높은 것으로 나타났으나, 처리간의 유의 한 차이는 인정되지 않았다. 전 실험기간 중의 평균 난중은 처리간에 큰 차이는 없는 것으로 나타났다. AC $1 \%$ 및 $2 \%$ 첨가구에서의 일당 사료섭취량은 대조구와 AC $0.5 \%$ 첨가구에 비 해 다소 높았으나, 통계적으로 유의성 있는 차 이는 아니었다.

산란계에서 목탄 및 목초액을 급여한 후 산 란율을 조사한 선행연구의 결과들은 다소 상이 한 결과를 보이고 있다. Hasan 등(2001)은 산란 계에서 목탄을 $1 \%$ 에서 $4 \%$ 까지 수준별로 첨가 급여한 연구에서 산란율, 난중 및 사료섭취량 에는 큰 변화가 없었다고 보고하였다. 반면, 민 병준 등(2002)은 활성 야자탄 급여 후에 산란율 이 유의하게 증가하는 결과를 관찰하였다. 이 석순(1999) 역시 산란계 사료 내 숯을 첨가하였 을 때 산란율이 개선되었다고 보고하였으며, 목초액을 첨가한 연구에서도 산란율 개선에 도 움이 된다는 긍정적인 연구 결과를 보고한 바 있다(이홍룡과 류경선, 2001).

본 실험에서는 대조구에 비해 AC $1 \%$ 및 $2 \%$ 첨가구에서 산란율이 다소 높아지는 경향이 관 찰되었으나, 통계적으로 유의한 차이는 인정되 지 않았다. 전 실험기간의 평균 난중에서도 처 리간에 큰 차이는 없었으며, 이는 목탄 및 목 초액을 급여한 선행 연구에서 난중에는 큰 차 이가 없다는 연구 결과들과 유사한 것으로 생 각된다. 일당 사료섭취량에서는 $\mathrm{AC} 1 \%$ 와 $2 \%$ 첨가구에서 대조구에 비해 다소 높게 나타났는
데, $\mathrm{AC}$ 를 대체함으로서 사료 내 에너지 수준이 다소 낮아졌다는 점에 기인한 것으로 사료되었 다.

\section{2. 난질 및 난각질에 미치는 영향}

실험사료 내 $\mathrm{AC}$ 의 첨가 급여가 난질 및 난 각질에 영향에 대한 결과를 Table 3에 나타내 었다. $\mathrm{AC}$ 의 첨가 수준이 증가함에 따라 난각 강도는 유의하게 증가하거나 증가하는 경향을 나타내었는데, $\mathrm{AC} 2 \%$ 첨가구에서의 난각강도 는 대조구에 비해 유의하게 개선되었으며 $(\mathrm{P}<0.05)$, 통계적으로 유의한 차이는 인정되지 않았으나 $\mathrm{AC} 0.5 \%$ 및 $\mathrm{AC} 1 \%$ 첨가구의 난각 강도 역시 대조구의 결과에 비해 다소 개선되 는 결과가 관찰되었다. 대조적으로 난각 두께 에서는 처리간에 큰 차이가 없는 것으로 나타 났다. 대조구에 비해 $\mathrm{AC}$ 를 첨가 급여한 모든 처리구에서 난황색이 유의하게 개선되는 결과 가 관찰되었다 $(\mathrm{P}<0.05)$.

성기승(1996)은 산란계를 공시하여 목초액이 첨가된 활성탄을 급여한 연구에서 난각 강도와 난황색이 향상되었다고 보고하였으며, 이홍룡 과 류경선(2001) 역시 목초액의 첨가 급여에 의 해 난각 강도가 개선되는 경향을 관찰한 바 있 다. 반면 활성 야자탄을 급여한 연구에서는 오 히려 난각 강도와 난각 두께가 감소하며, 난황 색이 다소 증가한 경향은 있었으나 유의한 차 이는 아니었다고 보고한 바 있다(민병준 등, 2002). 선행연구 결과를 정리해 보면 목초액의 첨가 및 활성탄과 목초액의 혼합 급여 후에 난

Table 3. Effects of dietary activated charcoal on egg and eggshell qualities in laying hens $^{1), 2)}$

\begin{tabular}{lcccc}
\hline & AC $0 \%$ & AC 0.5\% & AC 1\% & AC 2\% \\
\hline \hline Eggshell breaking strength, kg/cm & $3.06 \pm 0.05^{\mathrm{b}}$ & $3.16 \pm 0.07^{\mathrm{b}}$ & $3.19 \pm 0.06^{\mathrm{b}}$ & $3.42 \pm 0.06^{\mathrm{a}}$ \\
Eggshell thickness, mm & $0.36 \pm 0.02$ & $0.36 \pm 0.02$ & $0.36 \pm 0.02$ & $0.36 \pm 0.01$ \\
Egg yolk color & $7.4 \pm 0.1^{\mathrm{b}}$ & $7.6 \pm 0.1^{\mathrm{a}}$ & $7.6 \pm 0.1^{\mathrm{a}}$ & $7.6 \pm 0.1^{\mathrm{a}}$ \\
Egg yolk index, mm & $0.429 \pm 0.00^{\mathrm{b}}$ & $0.429 \pm 0.00^{\mathrm{b}}$ & $0.432 \pm 0.01^{\mathrm{ab}}$ & $0.438 \pm 0.00^{\mathrm{a}}$ \\
Haugh unit & $72.90 \pm 0.95^{\mathrm{b}}$ & $72.95 \pm 1.07^{\mathrm{b}}$ & $73.52 \pm 1.04^{\mathrm{b}}$ & $77.35 \pm 1.01^{\mathrm{a}}$ \\
\hline
\end{tabular}

\footnotetext{
1) Abbreviation used : AC, activated charcoal.

2) Means \pm SE.

a,b Values with different superscripts differ significantly $(\mathrm{P}<0.05)$.
} 
각질 개선 및 난황색 개선 효과가 있었으나, 활성탄만을 단독으로 급여했을 경우 난각질이 개선되거나(Hasan 등, 2001), 또는 큰 영향이 없 는 것으로 나타났다(민병준 등, 2002). 본 연구 에서는 난각 강도와 난황색이 $\mathrm{AC}$ 첨가에 의해 유의하게 개선되는 효과가 관찰되어 상기의 선 행연구 결과를 뒷받침하는 유사한 결과가 관찰 되었다.

$\mathrm{AC}$ 의 급여에 의한 난황색의 개선 효과에 대 해서는 명확히 설명하기는 어렵지만, 목탄과 목초액이 공시계의 체내에서 난황 내 생리활성 을 발휘하여 $\mathrm{Ca}$ 대사와 사료 내 xanthophyll의 이행에 촉진적 역할을 함으로서 생산물에 긍정 적 영향을 미친 것으로 생각된다. 난각 강도가 향상된 결과에 대해서는 활성탄 내의 조회분과 광물질이 난각질 개선에 도움이 된다는 설명 (Hasan 등, 2001)이 본 실험에서도 유사하게 재 현된 것으로 생각된다.

본 연구에서는 $\mathrm{AC}$ 의 첨가 수준이 증가함에 따라 Haugh unit가 유의하게 증가하거나 증가 하는 경향을 나타내었다. 특히 $\mathrm{AC} 2 \%$ 첨가구 의 전 실험기간 평균 Haugh unit는 대조구 또 는 $\mathrm{AC}$ 첨가 수준이 낮았던 다른 처리구에 비 해 유의하게 증가하는 결과가 얻어졌다 $(\mathrm{P}<0.05)$. 난황계수 역시 AC $2 \%$ 첨가구에서 대조구에 비해 유의하게 증가하였다.

坂井田 (1987)는 산란계 사료 내에 활성탄을 첨가하여 급여했을 때 난백고와 난황높이가 향 상됨으로서 활성탄이 고부가가치 계란 생산을 위한 좋은 재료로서 사용될 수 있음을 시사한
바 있다. 민병준 등(2002) 역시 활성 야자탄을 급여한 연구에서도 계란의 난황계수가 유의하 게 증가하였다는 유사한 결과를 보고하였다. 한편 이상진 등(1994)은 산란계 사료 내 목초액 의 첨가 급여가 생산된 계란의 Haugh unit를 유의하게 개선시키는 긍정적인 결과를 관찰한 바 있다. 본 연구에서도 $\mathrm{AC}$ 를 첨가 급여함으로 서 Haugh unit와 난황계수가 다소 증가하거나 유의하게 개선되는 결과가 관찰됨으로서 $\mathrm{AC}$ 가 계란의 신선도 및 부가가치를 향상시킬 수 있 음을 시사하는 결과가 얻어졌다.

Table 4에 나타낸 바와 같이 AC의 첨가 급여 는 난황막 강도에 유의한 영향을 미치지 않았 던 것으로 나타났다. 실험 3주째 생산된 계란 의 난황막 강도는 1 일 보관한 계란 시료에 비 해 7일 및 14 일간 보관 후에는 난황막 강도가 다소 낮아지는 결과가 관찰되었는데, $\mathrm{AC} 2 \%$ 첨가구에서는 난황막 강도의 저하가 다른 처리 구에 비해 감소하는 경향이 나타났다. 실험 5 주째에 생산된 계란에서도 실험 3주째와 유사 한 결과가 얻어졌으나 통계적으로 유의한 차이 는 인정되지 않았다. AC의 첨가 급여 후 난황 막 강도를 지표로 조사한 계란 저장성에서는 유의한 차이를 발견하지는 못하였으나, 시간경 과에 따른 난황막 강도의 저하를 막는데 다소 $\mathrm{AC}$ 가 도움이 될 수 있음이 시사되었다. 이후에 는 난황막 강도 외에도 저장기간에 따른 Haugh unit의 변화, 난백 $\mathrm{pH}$ 변화 등 계란의 저장성에 관련된 다양한 항목에 대한 조사가 필요할 것 으로 생각된다.

Table 4. Effect of dietary activated charcoal on egg yolk membrane strength in laying hens ${ }^{1), 2)}$

\begin{tabular}{ccccc}
\hline Storage time & AC $0 \%$ & AC $0.5 \%$ & AC $1 \%$ & AC $2 \%$ \\
\hline \hline 3 weeks & $\ldots \ldots \ldots \ldots \ldots \ldots \ldots \ldots \ldots \ldots \ldots \ldots \ldots \ldots \ldots \ldots \ldots \ldots \ldots \ldots \ldots \ldots \ldots \ldots \ldots \ldots \ldots \ldots \ldots \ldots \ldots \ldots \ldots \ldots \ldots \ldots \ldots \ldots \ldots \ldots \ldots \ldots \ldots \ldots \ldots$ \\
$1 \mathrm{~d}$ & $160.1 \pm 6.9$ & $151.1 \pm 8.0$ & $169.0 \pm 7.9$ & $163.5 \pm 6.0$ \\
$7 \mathrm{~d}$ & $117.6 \pm 6.8$ & $127.9 \pm 9.1$ & $139.2 \pm 8.0$ & $137.8 \pm 10.0$ \\
$14 \mathrm{~d}$ & $98.80 \pm 7.0$ & $102.8 \pm 3.3$ & $119.4 \pm 6.5$ & $122.8 \pm 8.1$ \\
5 weeks & & & & \\
$1 \mathrm{~d}$ & $176.9 \pm 4.6$ & $176.3 \pm 7.5$ & $185.1 \pm 9.2$ & $177.1 \pm 9.5$ \\
$7 \mathrm{~d}$ & $136.1 \pm 5.1$ & $138.0 \pm 5.7$ & $145.1 \pm 5.9$ & $140.2 \pm 8.0$ \\
$14 \mathrm{~d}$ & $113.8 \pm 3.8$ & $126.5 \pm 6.0$ & $131.9 \pm 4.7$ & $128.3 \pm 6.5$ \\
\hline
\end{tabular}

1) Abbreviation used : AC, activated charcoal.

2) Means $\pm \mathrm{SE}$. 
3. 혈청 내 GOT, GPT 활성 및 콜레스테롤 분획에 미치는 영향

실험사료 내 $\mathrm{AC}$ 를 다양한 수준으로 첨가하 여 급여했을 때 혈청 내 GOT, GPT 활성 및 콜 레스테롤에 미치는 영향에 대한 결과를 Table 5에 나타내었다. 혈액 내 GOT 수준은 대조구 에서 $151.76 \mathrm{U} / \mathrm{l}$ 이었던 것에 비해 $\mathrm{AC} 0.5 \%$, $1 \%$ 및 $2 \%$ 첨가구에서 각각 $148.64 \mathrm{U} / \mathrm{l}, 140.63$ $\mathrm{U} / /$ 및 $117.78 \mathrm{U} / l$ 로 $\mathrm{AC}$ 첨가 수준이 증가함에 따라 감소하는 결과가 관찰되었으나, 통계적으 로 유의한 차이는 인정되지 않았다. GPT 수준 에서는 처리구간에 큰 차이는 없는 것으로 나 타났다. 혈액 내 총콜레스테롤 농도는 대조구 에 비해 $\mathrm{AC}$ 를 첨가함에 따라 다소 감소하는 결과를 나타내었으나 유의차는 인정되지 않았 다. HDL-콜레스테롤 농도에서도 처리구간에 큰 차이가 없었던 것으로 나타났다.

간 기능의 이상 여부를 측정하는 지표로 이 용되고 있는 혈청 GOT 및 GPT 수준을 조사한 결과에서 $\mathrm{AC}$ 는 첨가 수준에 관계없이 대조구 와 차이가 없었으며, 이는 $\mathrm{AC}$ 가 체내 대사에 부정적인 영향을 미치지 않음을 시사하는 결과 이다. 가축에게 활성탄과 목초액을 공급하여도 큰 부작용은 없다고 한 선행연구의 결과들(성 기승 등, 1997; 이석순, 1999)과 유사한 결과로 판단된다.

김영직과 박창일(2001)은 육계사료에 활성탄 을 첨가한 실험에서 혈액 내 콜레스테롤 농도 에는 영향이 없었다고 하였으며, 민병준 등 (2002) 역시 산란계를 공시한 연구에서 활성 야 자탄이 첨가된 사료를 급여했을 때 $\mathrm{HDL}$-콜레
스테롤 수준이 감소하는 경향이 있었으나, 유 의적인 차이는 아니었다고 보고하였다. 이홍룡 과 류경선(2001) 역시 목초액이 첨가된 산란계 사료를 급여하였을 때 혈장 내 총콜레스테롤 수준이 다소 낮아졌으나 유의한 차이는 아니었 다는 결과를 관찰한 바 있다.

\section{4. 난황 내 총지질, 콜레스테롤 함량 및 지 방산 조성에 미치는 영향}

실험사료 내 $\mathrm{AC}$ 를 다양한 수준으로 첨가하 여 급여했을 때 난황 내 총지질과 콜레스테롤 함량 및 지방산 조성에 미치는 영향에 대한 결 과를 Table 6에 나타내었다. 난황 내 총지질 함 량은 대조구에서 가장 높았고 $\mathrm{AC} 2 \%$ 첨가구 에서 가장 낮았으며, $\mathrm{AC}$ 첨가 수준의 증가에 따라 총지질 함량이 선형적으로 감소하는 경향 이 관찰되었다. AC $1 \%$ 및 $2 \%$ 첨가구의 난황 내 총지질 함량은 대조구와 $\mathrm{AC} 0.5 \%$ 첨가구에 비해 유의하게 낮은 것으로 나타났다 $(\mathrm{P}<0.05)$. 난황 내 총 콜레스테롤 함량은 대조구와 $\mathrm{AC}$ 첨가구간에 큰 차이는 없는 것으로 나타났다.

김영직과 박창일(2001)은 육계 사료에 활성탄 을 급여했을 때 계육 내 지방 함량이 유의하게 감소하였다고 보고하였는데 $(\mathrm{P}<0.05)$, 활성탄이 지방의 생합성 능력을 저하시키기 때문일 것으 로 추론하였다. 성기승 등(1997)은 산란계 사료 에 목초액이 첨가된 활성탄을 급여하였을 때 난황 내 콜레스테롤 수준에는 아무런 영향이 없다고 하였고, 坂井田(1987)와 이상진 등(1994) 역시 산란계 사료 내 활성탄 첨가 시 난황 콜 레스테롤의 함량에는 영향을 미치지 않았다고

Table 5. Effect of dietary activated charcoal on enzyme activities and cholesterol concentrations of serum in laying hens ${ }^{1), 2)}$

\begin{tabular}{lrrrr}
\hline Treatments & \multicolumn{1}{c}{ AC $0 \%$} & \multicolumn{1}{c}{ AC $0.5 \%$} & \multicolumn{1}{c}{ AC $1 \%$} & \multicolumn{1}{c}{ AC $2 \%$} \\
\hline \hline GOT, U/ l & $151.76 \pm 8.35$ & $148.64 \pm 7.32$ & $140.63 \pm 8.26$ & $117.78 \pm 12.06$ \\
GPT, U/ l & $22.67 \pm 6.90$ & $33.54 \pm 10.61$ & $28.83 \pm 4.75$ & $25.67 \pm 7.40$ \\
Total-C, mg/dl & $129.46 \pm 7.73$ & $120.25 \pm 8.40$ & $113.97 \pm 15.11$ & $113.81 \pm 14.50$ \\
HDL-C, mg/dl & $75.08 \pm 4.88$ & $78.80 \pm 10.86$ & $87.00 \pm 13.79$ & $67.66 \pm 8.54$ \\
\hline
\end{tabular}

\footnotetext{
1) Abbreviation used: AC, activated charcoal; GOT, glutamic-oxaloacetic transaminase; GPT, glutamic-pyruvic transaminase; Total-C, total cholesterol; HDL-C, high density lipoprotein-cholesterol.

2) Means \pm SE.
} 
Table 6. Effect of dietary activated charcoal on cholesterol, total lipid contents and fatty acid composition of egg yolk in laying hens ${ }^{1), 2), 3)}$

\begin{tabular}{|c|c|c|c|c|}
\hline & $\mathrm{AC} 0 \%$ & AC $0.5 \%$ & $\mathrm{AC} 1 \%$ & AC $2 \%$ \\
\hline Egg yolk cholesterol, mg/g & $13.22 \pm 0.48$ & $13.21 \pm 0.52$ & $13.19 \pm 0.42$ & $13.09 \pm 0.43$ \\
\hline Egg yolk total lipid, \% & $33.03 \pm 0.34^{\mathrm{a}}$ & $32.96 \pm 0.99^{\mathrm{a}}$ & $27.99 \pm 0.78^{\mathrm{b}}$ & $25.94 \pm 1.04^{\mathrm{b}}$ \\
\hline C14:0 & $0.32 \pm 0.04$ & $0.37 \pm 0.01$ & $0.37 \pm 0.02$ & $0.32 \pm 0.03$ \\
\hline C14:1 $\omega 5$ & $0.07 \pm 0.01$ & $0.07 \pm 0.01$ & $0.09 \pm 0.01$ & $0.08 \pm 0.01$ \\
\hline C16:0 & $24.65 \pm 0.22$ & $24.40 \pm 0.31$ & $25.01 \pm 0.42$ & $24.50 \pm 0.33$ \\
\hline C16:1 $\omega 7$ & $2.43 \pm 0.11$ & $2.55 \pm 0.13$ & $2.88 \pm 0.22$ & $2.80 \pm 0.17$ \\
\hline C18:0 & $8.99 \pm 0.58$ & $8.22 \pm 0.17$ & $7.98 \pm 0.22$ & $8.08 \pm 0.21$ \\
\hline C18:1 $\omega 9$ & $42.22 \pm 0.55$ & $43.25 \pm 0.65$ & $42.39 \pm 0.61$ & $43.39 \pm 0.40$ \\
\hline C18:2 $\omega 6$ & $13.29 \pm 0.65$ & $12.95 \pm 0.89$ & $13.21 \pm 0.77$ & $12.67 \pm 0.62$ \\
\hline C18:3 $\omega 3$ & $0.25 \pm 0.01$ & $0.29 \pm 0.02$ & $0.26 \pm 0.01$ & $0.24 \pm 0.01$ \\
\hline C20:1 $\omega 9$ & $0.26 \pm 0.01$ & $0.28 \pm 0.01$ & $0.45 \pm 0.19$ & $0.26 \pm 0.01$ \\
\hline C20:2 $\omega 6$ & $0.17 \pm 0.01$ & $0.19 \pm 0.02$ & $0.16 \pm 0.01$ & $0.18 \pm 0.01$ \\
\hline C20:4 $\omega 6$ & $1.89 \pm 0.05$ & $1.74 \pm 0.03$ & $1.73 \pm 0.04$ & $1.81 \pm 0.07$ \\
\hline C22:6 $\omega 3$ & $0.52 \pm 0.02$ & $0.48 \pm 0.01$ & $0.48 \pm 0.01$ & $0.46 \pm 0.02$ \\
\hline SFA & $33.96 \pm 0.62$ & $33.00 \pm 0.34$ & $33.37 \pm 0.51$ & $32.90 \pm 0.28$ \\
\hline MUFA & $44.99 \pm 0.59$ & $46.15 \pm 0.73$ & $45.81 \pm 0.73$ & $46.53 \pm 0.52$ \\
\hline PUFA & $16.26 \pm 0.67$ & $15.81 \pm 0.95$ & $16.00 \pm 0.79$ & $15.51 \pm 0.71$ \\
\hline Total $\omega 3$ & $0.76 \pm 0.02$ & $0.77 \pm 0.03$ & $0.74 \pm 0.02$ & $0.70 \pm 0.03$ \\
\hline Total $\omega 6$ & $15.50 \pm 0.66$ & $15.04 \pm 0.93$ & $15.27 \pm 0.80$ & $14.81 \pm 0.69$ \\
\hline$\omega 6 / \omega 3$ & $20.42 \pm 0.94$ & $19.47 \pm 0.91$ & $20.83 \pm 1.23$ & $21.04 \pm 0.51$ \\
\hline
\end{tabular}

1) Abbreviation used : AC, activated charcoal.; SFA, saturated fatty acid; MUFA, monounsaturated fatty acid; PUFA, polyunsaturated fatty acid.

2) Means \pm SE.

a,b Values with different superscripts differ significantly $(\mathrm{P}<0.05)$.

3) Number of carbon atoms: number of double bonds, followed by the position of the first double bond related to the methyl end.

함으로서 본 연구와 유사한 결과를 보고한 바 있다.

난황 내 지방산 중에는 oleic acid (C18:1 $\omega$ 9), palmitic acid (C16:0), linoleic acid (C18:2 $\omega$ 6)의 순으로 많았으며, 이들 지방산의 비율에서 처 리간에 큰 차이는 없는 것으로 나타났다. 총 포화지방산, 총 단일불포화지방산, 총 다가불포 화지방산, 총 $\omega 3$ 지방산 및 총 $\omega 6$ 지방산의 비율에서도 처리간에 특별한 차이는 인정되지 않았다. 성기승 등(1997)과 이홍룡과 류경선 (2001)은 산란계 사료 내에 목초액이 첨가된 활 성탄과 목초액만을 첨가하여 급여한 연구에서 난황 내 지방산 조성에 변화가 있었으며, 특히 다가불포화지방산의 함량이 높아졌다고 보고하
였다. 그러나 이들 연구자들은 어떠한 이유에 서 지방산 조성이 변화하였는지는 명확히 설명 하지 못하였다. 난황의 지방산 조성은 사료 내 지방산 조성에 직접적인 영향을 받기 때문에 본 연구에서 난황의 지방산 조성이 변하지 않 은 것이 당연한 결과로 사료되지만, 난황을 포 함하여 축산물 내 지방산 조성을 변화시킬 가 능성에 대해서는 추후 연구를 통해 충분한 검 증이 이루어져야 할 것이다.

$$
\text { IV. 요 약 }
$$

본 연구의 목적은 목초액 함유 활성탄 (activated charcoal, AC)의 급여가 산란계에서 
난생산성, 난질과 난각질, 혈액 내 콜레스테롤 분획과 효소 활성 및 난황 내 지질 조성의 변 화에 미치는 영향을 규명하기 위해 실시하였 다. 총 192수의 56주령 Lohmann 갈색 계통의 실용 산란계를 4 개의 처리구로 나누어 $0 \% \mathrm{AC}$, $0.5 \% \mathrm{AC}, 1 \% \mathrm{AC}$ 및 $2 \% \mathrm{AC}$ 를 함유하는 실험 사료를 각각 5 주간 급여하였다. 사료 섭취량과 난 생산성은 매일 기록하였으며 할란 검사는 주 단위로 실시하였다. 사양실험 종료 시 각 공시계로부터 혈액을 채취하여 혈청 콜레스테 롤 농도, GOT 및 GPT 활성을 조사하였다. 실 험 종료일에 수거한 계란을 할란하여 난질을 검사한 후 난황을 채취하여 난황 내 콜레스테 롤 함량과 지방산 조성을 측정하였고, 실험 3 주와 5 주의 계란을 1 일, 7 일, 14 일간 저장 한 후 난황막 강도를 측정하였다.

난 생산성, 사료 섭취량 및 난황막 강도에서 는 처리간에 큰 차이가 관찰되지 않았으나, $\mathrm{AC}$ $2 \%$ 첨가구에서 난각강도와 Haugh unit의 유의 한 개선이 관찰되었다 $(\mathrm{P}<0.05)$. 난황계수 역시 $\mathrm{AC} 2 \%$ 첨가구에서 유의하게 증가하였으며, 난 황색은 대조구에 비해 $\mathrm{AC}$ 를 첨가한 모든 처리 구에서 유의하게 개선되었다 $(\mathrm{P}<0.05)$. 저장시간 의 경과에 따른 계란의 보존성을 난황막 강도 를 지표로 조사하였을 때 통계적으로 유의한 차이는 없었으나, 활성탄의 첨가가 난황막 강 도의 저하를 다소 완화시키는 효과가 관찰되었 다. 혈청 내 GOT 및 GPT 농도에서는 처리구간 에 큰 차이가 없었으며, 혈청 콜레스테롤과 $\mathrm{HDL}$-콜레스테롤 농도에서도 $\mathrm{AC}$ 첨가 효과는 인정되지 않았다. 난황 내 총지질 함량은 선형 적으로 감소하였는데, $\mathrm{AC} 1 \%$ 와 $2 \%$ 첨가구에서 유의하게 낮아지는 결과를 나타내었다 $(\mathrm{P}<0.05)$. 난황 내 총 콜레스테롤 함량과 지방산 조성에 서는 처리간에 큰 차이는 나타나지 않았다.

본 연구에서는 산란계 사료 내 $\mathrm{AC}$ 의 첨가 급여가 난각 강도, Haugh unit 및 난황색, 난황 계수를 개선시킴으로서 고품질 계란 생산을 위 한 기능성 첨가제로서 활용이 가능할 것으로 판단되었다.

(색인어 : 활성탄, 목초액, 생산성, 난각강도, 호 우유니트, 산란계)

$$
\mathrm{V} \text {. 사 사 }
$$

본 연구는 2004년도 산림청 국립산림과학원 일반과제의 연구비로 수행하였습니다.

\section{VI. 인 용 문 헌}

1. Bamberg, J. B., Hanneman Jr. and Towill, L. E. 1986. Effects of filtration through activated carbons on peroxide, thiobarbituric acid and carbonyl values of autoxidized soybean oil. J. Amer. Oil Chem. Soc. 68:561-565

2. Bradley, K. J., Hamdy, M. K. and Toledo, R. T. 1987. Physicochemical factors affecting ethanol absorption by activated carbon. Biotechnol. Bioeng. 29:445-452.

3. Buck, W. B. and Bratich, P. M. 1985. Experimental studies with activated charcoals and oils in preventing toxicoses. Proc. Annu. Meet. Am. Assoc. Vet. 24:193-200.

4. Dalvi, R. R. and Ademoyer, A. A. 1984. Toxic effects of aflatoxin B1 in chickens given feed contaminated with Aspergillus flavus and reduction of the toxicity by activated charcoal and some chemical agents. Avian Dis. 28:61-69.

5. Duncan, D. B. 1955. Multiple range and multiple F test. Biometer. 11:1-42.

6. Folch, G., Lees, M. and Stanley, G. H. S. 1957. A simple method for the isolation and purification of total lipids from animal tissues. J. Biol. Chem. 226-467.

7. Guo, L., Bicki, T. J., Felsot, A. S. and Hinesly, T. D. 1991. Phytotoxicity of atrazine and alachlor in soil amended with sludge, manure and activated carbon. J. Environ. Sci. 26:513.

8. Hasan, R. K., Ilknur, U. and Murat, G. 2001. Effect of providing dietary wood(oak) charcoal to broiler chickens and laying hens. Animal Feed Sci. 90:213-226.

9. Hinshelwood, M., Kamel, M., Dierschke, D. J. and Hauser, E. R. 1991. Effects of charcoalextracted follicular fluid on reproductive function 
in postpartum cows. Domest. Anim. Endocrinol. 8: 37-54.

10. Kishmoto, S. and Sugiura, G. 1985. Charcoal as a soil conditioner. Symposium of forest products research international achievments and the future : 22-26 Apr. 1985 Pretoria. National Timber Research Institute of the South African Council for Scientific and Industrial Res. 5:12.23.1-12.23.16.

11. Mark, L. A., Sullivan, D. M., Smith, R. L. and Richer, E. F. 1986. Evaluation of direct saponification method for determination of cholesterol in meats. J. ASSOC. OFF. Anal. Chem. 69: 844-846.

12. National Research Council, 1994. Nutrient Requirements of Poultry, 11th ed. National Academy Press, Washington, DC.

13. SAS Institute. 2002. SAS/STAT User's Guide : Satistics. Version 8.1, 4th Editon. SAS Institute Inc., Cary, NC.

14. Sauter, E. A., Stadelman, W. J., Harns, V. and Mclaren, B. A. 1951. Methods for measuring yolk index. Poultry Sci. 30:629-630.

15. 김광은, 박성범, 안경모. 2000. 숮과 목초액. 한림 저널사. pp. 77.

16. 김성훈, 김한성. 1998. 목초액의 약리 및 임상 효 능과 연구방향. 한의학논문집, 7:831-835.

17. 김영직, 박창일. 2001. 활성탄의 첨가가 육계의 생산성 및 이화학적 특성에 미치는 영향. 한국축 산식품학회지 21:24-21.

18. 문성실. 2002. 활성탄의 첨가급여가 돈육의 이화 학적 특성과 지방산 조성에 미치는 효과. 한국축 산식품학회지 22:145-150.
19. 민병준, 김인호, 이원백, 홍종옥, 김지훈, 권오석, 이상환. 2002. 산란계에서 활성야자탄의 첨가가 계란의 품질 및 혈장 콜레스테롤 함량에 미치는 영향. 한국가금학회지 29:13-18.

20. 성기승. 1996. 활성탄 첨가 수준에 다른 계란의 특성 변화 연구. 건국대학교 석사학위논문.

21. 성기승, 노정해, 한찬규, 김영붕, 이복희, 정재홍, 맹원재. 1997. 목초액이 첨가된 활성탄의 급여가 계란의 이화학적 특성에 미치는 효과. 한국축산 식품학회지 17:162-170.

22. 이상진, 서옥석, 나재천, 박용윤. 1994. 양계산물 의 품질향상 연구., 산란계 사료에 대한 네카리치 첨가효과 시험. 축산시험장 일반위탁연구보고서.

23. 이석순. 1999. 숯과 목초액으로 사육한 저공해 계란 생산기술 개발. 현장애로기술개발사업. 농 업인개발 과제 요약 pp. 307-310.

24. 이홍룡, 류경선. 2001. 산란계 사료에 목초액의 첨가 급여가 생산성 및 계란품질에 미치는 영향. 동물자원학회지 43:655-662.

25. 坂井田. 1987. 高付加值商品の開發事例. 敎育大學.

26. 허광선, 신세건, 정의덕. 1998. 목초액을 이용한 쓰레기 매립지 침출수의 악취제거에 관한 연구. 한국환경과학회지. 117:7-8.

27. 황미자. 1995. 활성탄의 첨가가 비육돈의 성장률 과 사료 이용성 및 도체 성적에 미치는 영향. 건 국대학교 석사학위논문.

(접수일자 : 2005. 9. 22. / 채택일자 : 2006. 1. 4.) 